Zavadska D.V.

Ph.D. of Economics, Associate Professor,Odessa National Economic University (city Odessa), Ukraine; e-mail: zavadska.diana@ukr.net

Pelivan D.A. Master student, Odessa National Economic University (city Odessa), Ukraine; e-mail:darya_pelivan@mail.ru

\title{
DEFINITION OF STRATEGICAL COMPETITIVENESS OF THE BANKS IN ODESSA REGION IN TERMS OF REGIONAL DISPROPORTION
}

Abstract. In the article the methodological approach of using the analytic coefficient method or evaluation of the competitive environment in the regional banking market is proved. The basic stages of the analysis in accordance to this method's algorithm are disclosed. The results of numerical calculation procedure of the evaluation of loan and deposit imbalance in term of Odessa region are presented. Comparing methods are confirmed the possibility of its using under the rating score of competitiveness of banks in Odessa region. In the article method advantages are also market out, the usage algorithm on the matrix of the competitive position of the banking institution among the sectors of the banking market in Odessa region is represented.

Keywords: bank, regional banking system, imbalances, competitive environment, concentration, strategy.

Formulas: 8; fig.: 0; tabl.: 6; bibl.: 16.

JEL Classification: G 21, C 13, R 13.

Завадська Д.В. к.е.н., доцент, Одеський національний економічний університет (м. Одеса), Україна; e-mail: zavadska.diana@ukr.net

Пеліван Д.А.

Магістр, Одеський національний економічний університет (м. Одеса) Україна; e-mail:darya_pelivan@mail.ru

\section{ВИЗНАЧЕННЯ СТРАТЕГІЧНОЇ КОНКУРЕНТОСПРОМОЖНОСТІ БАНКІВ ОДЕСЬКОЇ ОБЛАСТІ В УМОВАХ РЕГІОНАЛЬНОЇ ДИСПРОПОРЦІЇ}

Анотація. У статті надано власне бачення щодо визначення сутності поняття «регіональний банк» шляхом аналізу переваг та недоліків розглянутих варіантів тлумачення вищевказаної категорії. Проаналізовано диспропорції розвитку банківської системи України в розрізі регіонів. Досліджено методики оцінки ефективності діяльності регіональних банківських систем, сформовано систему показників дослідження конкурентного середовища та вибору альтернативних стратегій розвитку регіональних банківських установ.

Ключові слова: банк, регіональна банківська система, дисбаланс, конкурентне середовище, концентрація, стратегія.

Формул: 8; рис.: 0; табл.: 6; бібл.: 16.

Завадская Д.В.

к.э.н., доцент, Одесский национальный экономический університет (г. Одесса), Украина e-mail: zavadska.diana@ukr.net

Пеливан Д.А. магистр, Одесский национальный экономический університет (2. Одесса), Украина e-mail:darya_pelivan@mail.ru

\section{ОПРЕДЕЛЕНИЕ СТРАТЕГИЧЕСКОЙ КОНКУРЕНТОСПОСОБНОСТИ БАНКОВ ОДЕССКОЙ ОБЛАСТИ В УСЛОВИЯХ РЕГИОНАЛЬНОЙ ДИСПРОПОРЦИИ}

Аннотация: В статье представлено свое видение к определению сущности понятия «региональный банк» путем анализа преимуществ и недостатков рассмотренных вариантов 
толкования вышеуказанной категории. Выделены причины диспропорций развития банковской системы Украины в разрезе регионов, подробно исследованы методики оценки эффективности деятельности региональных банковских систем и сформировано на их основе совокупность показателей для исследования конкурентной среды и выбора альтернативных стратегий развития региональных банковских учреждений.

Ключевые слова: банк, региональная банковская система, дисбаланс, конкурентная среда, концентрация, стратегия.

Формул: 8; рис.: 0; табл.: 6; библ.: 16.

Introduction. Performance of the bank establishments is one of the most important conditions of the proper work of the region. It mostly influences on the outlooks of the regional development, creating the conditions for making the investments, financing the speed of manufacturing and, as a result, increases the employment of population and their income. The effectiveness of fulfillment the tasks of the banks in the region depends on cooperation of the bank sector and regional economy. The problems of Ukrainian banking system include the imbalance of the regional component and lack of clearly defined scientific and methodological approaches for determination the competitiveness and prospects for development of the regional banks, which led to the choice of the theme and setting the research objectives.

Literature rewiew and the problem statement. There is a significant number of domestic and foreign researches devoted to the issues of the regional banks, such as: S. Gerasimchuk, L. Gulyaeva, O. Drugov, N. Koretska, K. Kremer, O. Kopyluk and others [1-7]. Despite the wide interpretation of banking issues on the regional level, the current state of the regional banking systems is mainly observed in economical literature as a whole, but there are not emphasized the complex techniques that will identify the alternative strategies of development of the separate regional banking institutions.

The article purpose is to create a system of activities to assess the competitive environment in the banking regional market, and the conditions of possible determination of strategic alternatives in reaching the market share by the banks, operating within the region. The solution of the following problems helps to reveal the aims: research of the dynamics of macro economical activities on the regional revel; assessment of the credit and deposit imbalance; rating of the strategic bank competitiveness; formation the matrix of competitive positions of banking institutions in the market sectors; range of strategic alternatives in reaching the market share of banking services in Odessa region.

Research results. One of the problems of the banking system in our country is the imbalance of its regional components. The experience and statistics of the European Union show: the more intense there is the development of entrepreneurship, the better there is the development of the banking system in the region [4, c. 58]. The quantity of regional banks in Ukraine is sufficiently small. Most of the local banks start to position themselves as Ukrainian ones and fulfill their activities on the territory of at least several regions of the country. However, they have an extensive branch network with authoritarian structures of the management. That means that instead of supporting the regional economy, the part of national banks branches contributes to the outflow of their financial resources. Such a situation causes the negative impact on the economic development of the country and requires the search for its optimization.

However, before proceeding to the study of practical issues within the chosen topic, it is worth analyzing of the internal matter of the categories such as "regional banking system", "regional bank" and their roles in the economical processes of the country. Initially we will examine the interpretation of the abovementioned concepts according to the legal standards. 
The definitions of these concepts are absent in the Law of Ukraine "On Banks and Bank activity" from 07.12.2000, that appears being a basic guiding line in the bank activities [8]. However it is worth bearing in mind that nowadays the market of the banking services is characterized by a high level of globalization and internationalization, that is why the question should be analyzed not only within its own concepts, but also in comparison with the international experience. The practice shows that it is similar to the local principles. For instance, the Federal Law "On the Banks and Bank Activity" from 02.12.1990 does not provide the definition of the term "regional bank", however it mentions the phrase "the banking system of the region" without any detailed explanation, meanwhile it indicates its basic components [9]. Therefore the abovementioned notion has rather economical than legal nature. Thereby we advise to postpone the consideration of this issue to economic studies.

In foreign practice the regional organizations are considered as being the credit ones in conditions of limitations to a certain territory. The local studies are not characterized by unambiguity and they consider the various features, that give the reason to classify the bank to its regional groups. But despite the list of features such a bank appears being a single component of the regional banking system. Thus the development of the region is not possible without the continuous cooperation of all the possible components of its banking sectors, such as: the territorial administration of the NBU (National Bank of Ukraine); regional banks; subsidiaries, branches, representative offices of regional and foreign banks; banking unions, associations, which are registered and operate within the region.

Therefore the implementation of an assessment of the competitive environment in the banking market is fulfilled in order to develop strategies for the regional bank development, we consider it necessary to construct the definition of the level of competitiveness, taking into account the effect of all the above mentioned elements, the relationship, that is revealed by implementation of its regional banking institutions, being the key elements of the system at the regional level of the following functions: serving, stabilizing, emissive, social, investing, transformational, stimulative and system-formational.

In our opinion, according to a critical analysis of the works of local and foreign researches [2, c. 65], the regional bank is a bank, that is registered in a particular region, mainly operates within its territory and is not systematically important for the government, at the same time the aim of its functioning combines the processes of achieving the goals and promotion the development of the region. There is a problem that appears in Ukraine connected with the fulfillment of the latest condition, because the local banking system is characterized as one having almost the exclusive regional concentration. In particular, more that the half of the fund is concentrated in 20 largest banks as in 01.10.2014. Their authorized capital comes to the amount of almost 115,3 million UAH. that is $63,5 \%$ of the total amount $[10 ; 11]$. As a result, in most of regions of the country rivalry unfolds between the local banks and territorial branches of the large banks. In general the concentration of the capital occurs only in a limited number of credit institutions, most of them are located in Kiev, making the regional banking systems unstable and deprives them the opportunity to develop their full potential. In order to determine the reasons of this phenomenon, we will consider some macroeconomic activities in the regional context (tabl. 1).

According to the table, on the territory of almost half of Ukrainian regions (Vinnytsia, Zhytomyr, Ivano-Frankivsk, Kirovohrad, Mykolaiv, Rivne, Ternopil, Kherson, Khmelnytsky, Cherkasy and Chernivtsi) there is not registered any single bank. The lack of legally independent banking institutions can cause the crisis in the regional development [12, p. 37]. Meanwhile, the percentage of banks' legal representatives in Kyiv region and Kyiv made up almost $66 \%$ on 01.01 .2013 . 
Table 1

Dynamics of the macro economical indexes on the regional level during

$01.01 .2013-01.10 .2014 *)$

\begin{tabular}{|c|c|c|c|c|c|c|c|c|c|c|}
\hline \multirow[t]{2}{*}{ Region } & \multicolumn{3}{|c|}{$\begin{array}{l}\text { Quantity of the banks, } \\
\text { registered in the region, in \% } \\
\text { from the total amount }\end{array}$} & \multicolumn{2}{|c|}{$\begin{array}{l}\text { Quantity of the } \\
\text { active companies } \\
\text { in \% from the total } \\
\text { amount }\end{array}$} & \multicolumn{3}{|c|}{$\begin{array}{l}\text { The total share of companies } \\
\text { that received the income, } \%\end{array}$} & \multicolumn{2}{|c|}{$\begin{array}{l}\text { Disposable income per } \\
\text { person, UAH }\end{array}$} \\
\hline & 2012 & 2013 & 2014 & 2012 & 2013 & 2012 & 2013 & 2014 & 2012 & 2013 \\
\hline Kyiv & 65,9 & 66,5 & 72,5 & 19,7 & 21,0 & 62,0 & 63,8 & 50,7 & 22520,1 & 26541,7 \\
\hline Vinnytsia & 0,0 & 0,0 & 0,0 & 2,9 & 2,8 & 68,0 & 70,1 & 65,7 & 19090,8 & 21734,9 \\
\hline Volyn & 0,6 & 0,5 & 0,0 & 2,0 & 1,9 & 62,0 & 64,5 & 57,0 & 16657,7 & 18806,9 \\
\hline $\begin{array}{l}\text { Dnipropet- } \\
\text { rovs`k }\end{array}$ & 8,0 & 7,1 & 5,9 & 6,9 & 6,7 & 60,6 & 63,5 & 55,2 & 24302,4 & 28771,6 \\
\hline Donetsk & 5,7 & 6,0 & 3,9 & 7,4 & 7,3 & 66,8 & 66,5 & 44,8 & 24890,3 & 29336,6 \\
\hline Zhytomyr & 0,0 & 0,0 & 0,0 & 2,3 & 2,3 & 60,8 & 63,0 & 62,5 & 18716,4 & 21288 \\
\hline Zakarpattia & 0,6 & 0,5 & 0,7 & 2,1 & 2,1 & 71,6 & 72,4 & 68,4 & 15002,4 & 17191,4 \\
\hline Zaporiggia & 1,7 & 1,6 & 2,0 & 3,9 & 3,7 & 62,1 & 65,4 & 58,5 & 23684,9 & 27107,6 \\
\hline $\begin{array}{l}\text { Ivano- } \\
\text { Frankivsk }\end{array}$ & 0,0 & 0,0 & 0,0 & 2,6 & 2,5 & 72,1 & 72,4 & 57,6 & 17732,6 & 20148,4 \\
\hline Kirovohrad & 0,0 & 0,0 & 0,0 & 2,1 & 2,0 & 73,5 & 74,2 & 50,9 & 18039,2 & 20553,7 \\
\hline Lugansk & 1,1 & 1,1 & 1,3 & 3,3 & 3,3 & 65,4 & 65,1 & 41,1 & 20879,9 & 24024,1 \\
\hline Lviv & 2,8 & 2,7 & 3,3 & 5,3 & 5,2 & 61,0 & 63,7 & 56,7 & 19204,4 & 21992,3 \\
\hline Mykolaiv & 0,0 & 0,0 & 0,0 & 2,9 & 2,8 & 67,0 & 71,8 & 52,3 & 20040,7 & 22878 \\
\hline Odessa & 4,5 & 4,9 & 4,6 & 6,0 & 5,9 & 63,9 & 67,7 & 53,6 & 19135 & 22224,4 \\
\hline Poltava & 1,7 & 1,6 & 1,3 & 3,0 & 2,9 & 68,2 & 67,8 & 59,5 & 20917,4 & 24027,2 \\
\hline Rivne & 0,0 & 0,0 & 0,0 & 1,9 & 1,9 & 61 & 63,3 & 61,9 & 17326,2 & 19859,8 \\
\hline Sumy & 0,6 & 0,5 & 0,7 & 1,9 & 1,9 & 63,8 & 63,6 & 59,6 & 19592,9 & 22582,3 \\
\hline Ternopil & 0,0 & 0,0 & 0,0 & 1,9 & 2,0 & 69,1 & 68,5 & 49,8 & 16351,3 & 18560,6 \\
\hline Kharkiv & 4,0 & 3,8 & 2,6 & 5,9 & 5,8 & 61,7 & 63,2 & 60,1 & 21787,8 & 24870 \\
\hline Kherson & 0,0 & 0,0 & 0,0 & 2,3 & 2,3 & 63,9 & 67,8 & 49,8 & 17654,3 & 19939,9 \\
\hline Khmelnytsky & 0,0 & 0,0 & 0,0 & 2,5 & 2,4 & 66,8 & 67,4 & 66,2 & 18738,2 & 21590,6 \\
\hline Cherkasy & 0,0 & 0,0 & 0,0 & 2,5 & 2,5 & 69,2 & 69,4 & 60,2 & 18246,3 & 20717,9 \\
\hline Chernygiv & 1,7 & 1,6 & 1,3 & 1,5 & 1,5 & 61,0 & 62,9 & 59,2 & 15992,5 & 18107,5 \\
\hline Chernivtsi & 0,0 & 0,0 & 0,0 & 2,0 & 2,0 & 66,1 & 66 & 61,6 & 19465 & 22769,6 \\
\hline
\end{tabular}

And it rose at the end of the third quarter of 2014 to $72.5 \%$ (6.5 percentage points), demonstrating a significant imbalance in the banking system of Ukraine. Such a situation may be connected with the fact that the Capital region has an average of $20 \%$ of active companies and one of the highest levels of income per person. Odessa region is characterized by the values close to the average and, along with Dnipropetrovs'k, Donetsk, Lviv and Kharkiv region can be classified to the second level of territorial concentration. That is why during the formation of marketing bank strategies of Odessa region it is advisable to use the experience of the banks, which operate on the above listed territories. Created by the banking system of assessing the value of the competitive environment in the regional market is one of important conditions of the successfully chosen strategy, for instance the method of determination of the credit-deposit imbalance in the region (tabl. 2). 
Evaluation of the competitive environment in the regional banking market

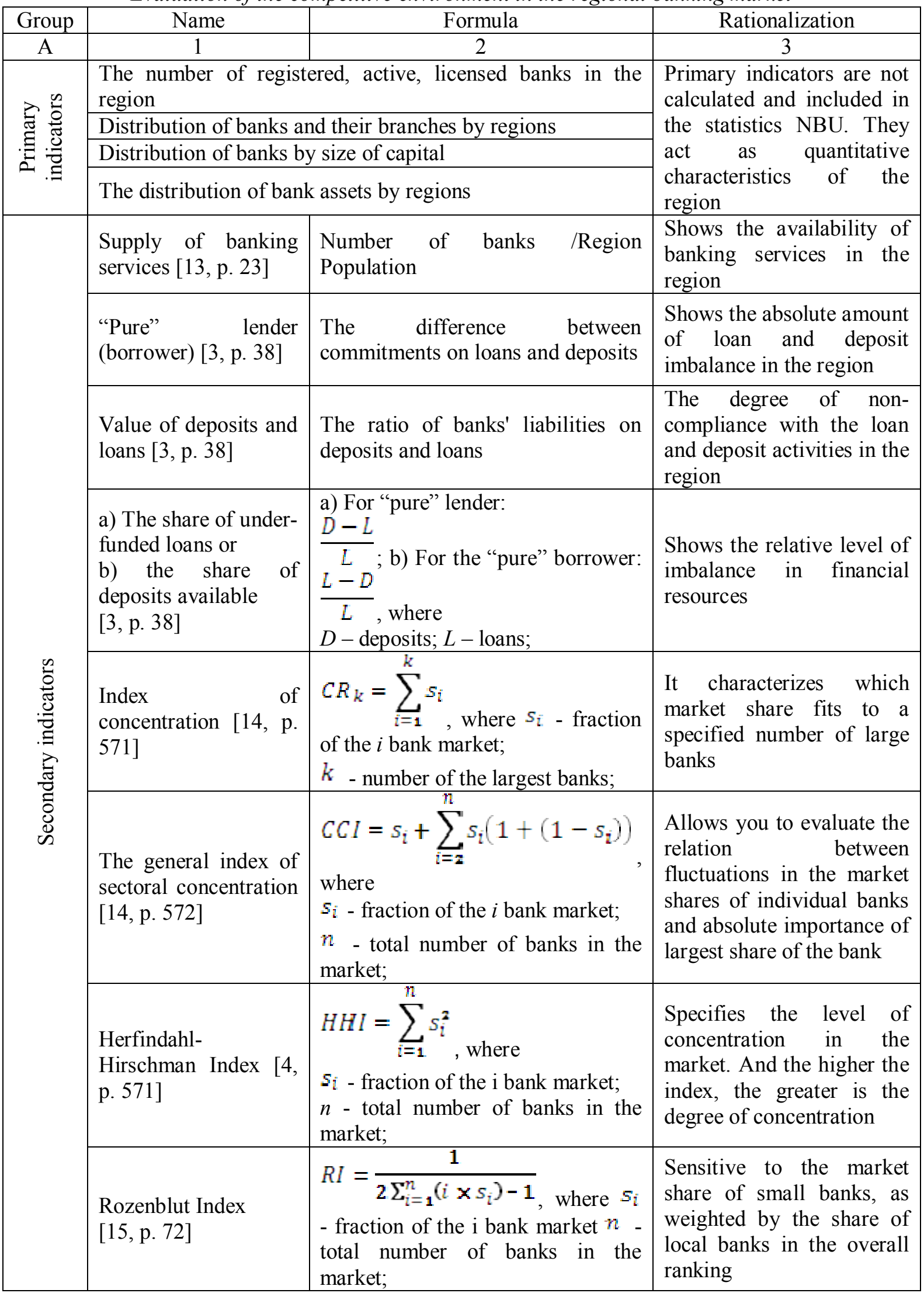


Extension table 2

\begin{tabular}{|c|c|c|c|}
\hline A & 1 & 2 & 3 \\
\hline 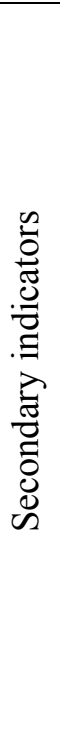 & $\begin{array}{l}\text { Hannaha and Kay Index } \\
{[14, \text { p. 574] }}\end{array}$ & $\begin{array}{l}H K I=\left(\sum_{i=1}^{n} s_{i}^{\alpha}\right)^{\frac{1}{1-\alpha}}, \text { where } s_{i}- \\
\text { fraction of the } i \text { bank market; } \\
n \text { - total number of banks in the } \\
\text { market; } \\
\alpha \text { - exponent influence; } \\
U=\left(\sum_{i=1}^{n} \llbracket s_{i}\left(s_{i} n^{(a-1)} / \alpha \rrbracket\right)\right)^{a} \\
\text { where } s_{i} \text { - fraction of the } i \text { bank } \\
\text { market; } \\
n \text { - total number of banks in the } \\
\text { market; } \\
\alpha \text { - exponent influence. }\end{array}$ & $\begin{array}{l}\text { They belong to the same } \\
\text { group of indicators and allow } \\
\text { you to compare the impact of } \\
\text { small and largest banks on } \\
\text { the market concentration } \\
\text {,due to changes in the degree } \\
\text { of influence of the market } \\
\text { share of individual banks }\end{array}$ \\
\hline
\end{tabular}

One of the banking system features in lots of developed countries is the presence of a significant number of relatively small banks, which are located in the regions and serve the regional companies. At the same time they have to withstand the competition of the global financial institutions. However, it is worth mentioning that the increase in the size of the bank does not form a steady competitive advantage, and the bankruptcy of the bank system will lead to negative social consequences. Algorithm of our study research is shown in tables 3-6.

Table 3

Evaluation of loan and deposit imbalance in terms of Odessa region in 2010, 2012 and 2014*)

\begin{tabular}{|l|c|c|c|}
\hline \multicolumn{1}{|c|}{ Activities } & \multicolumn{3}{c|}{ Period } \\
\cline { 2 - 4 } & 01.01 .2011 & 01.01 .2013 & 01.10 .2014 \\
\hline The amount of deposits & 31537308 & 50794214 & 46422740 \\
\hline The volume of loans & 53411891 & 46758658 & 56709589 \\
\hline $\begin{array}{l}\text { The absolute size of the loan and deposit } \\
\text { imbalance }\end{array}$ & -21874583 & 4035556 & -10286849 \\
\hline Value of deposits and loans & 0,5905 & 1,0863 & 0,8186 \\
\hline $\begin{array}{l}\text { The relative level of imbalance in financial } \\
\text { resources, including (\%): } \\
\text { a) share of under-funded loans; }\end{array}$ & 40,95 & $\mathrm{x}$ & 18,14 \\
\hline b) the proportion of free deposits & $\mathrm{x}$ & 7,94 & $\mathrm{x}$ \\
\hline
\end{tabular}

*) Source: constructed by the authors on [10] based on realistic data reporting banks

On 01.01.2011 and 01.10.2014 Odessa region represents as a "pure" borrower, whose share of the under-funded loans form the borrowed funds is $41 \%$ and $18 \%$. That means that the banks, which operate within the Odessa region, during these periods of time were using the funds from the other sources for implementing the credit operations. On 01.01.2013 an improvement of the situation in the region is noticed with the contradiction of the volumes of credit and deposit activities, it was close to the balance state, and the proportion of free deposits was estimated to $8 \%$. Thereafter there are not observed any clear trends of creditdeposit imbalance, and the region may act as a borrower and a lender, that allows the banks of 
Odessa region to choose the sales strategy of banking products, based on their competitive advantages and internal capabilities.

In order to implement the assessment of the competitive environment of banks in Odessa region we shall calculate the number of the concentration rate. The presence of a basic strategic area of management is one the conditions for assessment the competitiveness of banking institutions. Despite the consolidation of the bank accounting, the initial data is taken with the ratio of the quantity of bank branches located within the area in order to determine the level of concentration (tabl. 4).

Table 4

The evolution of the concentration in key segments of the banking market of Odessa region in 2010, 2012 and 2014*)

\begin{tabular}{|c|c|c|c|c|}
\hline \multirow{2}{*}{$\begin{array}{c}\text { Indicators of } \\
\text { market } \\
\text { concentration }\end{array}$} & Market sectors & \multicolumn{3}{|c|}{ Period } \\
\cline { 3 - 5 } & & 01.01 .2011 & 01.01 .2013 & 01.10 .2014 \\
\hline \multirow{3}{*}{$\begin{array}{c}\text { Index of } \\
\text { concentration }\end{array}$} & Assets & 0,5520 & 0,5628 & 0,6116 \\
\cline { 2 - 5 } & Deposits & 0,6001 & 0,6503 & 0,5728 \\
\cline { 2 - 5 } & Loans & 0,5315 & 0,5470 & 0,5544 \\
\cline { 2 - 5 } & Financial result & 0,8520 & 0,8632 & 0,8515 \\
\hline \multirow{3}{*}{$\begin{array}{c}\text { Herfindahl- } \\
\text { Hirschman Index }\end{array}$} & Assets & 465 & 522 & 692 \\
\cline { 2 - 5 } & Deposits & 566 & 617 & 593 \\
\cline { 2 - 5 } & Loans & 479 & 509 & 548 \\
\hline \multirow{4}{*}{\begin{tabular}{c} 
Rozenblut Index \\
\cline { 2 - 5 }
\end{tabular}} & Financial result & 1394 & 1692 & 1253 \\
\cline { 2 - 5 } & Assets & 0,0383 & 0,0407 & 0,0440 \\
\cline { 2 - 5 } & Deposits & 0,0419 & 0,0496 & 0,0465 \\
\hline \multirow{2}{*}{$\begin{array}{c}\text { The total index of } \\
\text { sectoral }\end{array}$} & Financial result & 0,0409 & 0,0413 & 0,0460 \\
\cline { 2 - 5 } concentration & Assets & 0,1778 & 0,1064 & 0,1029 \\
\cline { 2 - 5 } & Deposits & 0,2094 & 0,1976 & 0,2490 \\
\cline { 2 - 5 } & Loans & 0,1789 & 0,2196 & 0,2261 \\
\hline
\end{tabular}

*) Source: constructed by the authors on [10] based on realistic data reporting banks

According to the calculations presented in the table, the market share of 9 largest banks ranged from 53\% - 61\% in all market segments, except the financial result, where the value was a bit more than $85 \%$ during the whole period, that is connected with a significant loss ratio of the banking system in general. This conclusion is confirmed by the rest of the calculated figures. So Rosenbluth index, which is sensitive to the market share of small banks, is in the range $0.039-0.049$ (except the sector "financial result", where it is close to 0.11). The overall index of industry concentration in most cases varies from 0,18 to 0.25 , which is four times less than the threshold value, that is, for the Odessa region monopoly is not promising phenomenon: a low level of concentration, and therefore the majority of banks are on the equal conditions, which allows to assess the competitive potential of selected banks in a better way using the method T. Diachenko [16]. The content of the methodology is to calculate the indexes of competitiveness in four areas: assets, liabilities, equity and financial results. For comparison, we selected five banks that have branches in Odessa region, including Kredobank and VS bank, registered in Lviv, Investbank, Misto Bank and USB Bank, that officially belong to the banks of Odessa region (tabl. 5).

According to the research, given in tabl. 4, Lviv bank Kredobank has the highest level of competitiveness, in the structure of its equity investments of PKO Bank Polska SA come to the amount of $99.6 \%$. Banks, which are registered in Odessa area, regardless of the participation of foreign capital, are less competitive in comparison to the nonregional ones. 
Table 5

Rating score of competitiveness of banks during 01.01.2011-01.10.2014 *)

\begin{tabular}{|c|c|c|c|c|c|}
\hline \multirow{2}{*}{ Index } & \multicolumn{5}{|c|}{ Name of the bank } \\
\cline { 2 - 6 } & Kredobank & VS Bank & Invest-bank & Misto Bank & USB Bank \\
\hline Competitiveness of assets & 0,0000 & 0,4520 & 0,8929 & 0,6545 & 0,7756 \\
\hline Competitiveness of liabilities & 0,0000 & 0,4824 & 0,9001 & 0,6224 & 0,8576 \\
\hline $\begin{array}{c}\text { Competitiveness of capital } \\
\text { The competitiveness of the } \\
\text { financial result }\end{array}$ & 0,0116 & 0,3613 & 0,8442 & 0,5450 & 0,5130 \\
\hline Total Score & 0,8136 & 0,6314 & 0,8403 & 0,8940 & 0,7699 \\
\hline Rating & 0,1843 & 0,0668 & 0,0003 & 0,0063 & 0,0036 \\
\hline
\end{tabular}

*) Source: constructed by the authors on [10] based on realistic data reporting banks

This situation negatively affects the development of Odessa region, because in the future it may lead to the deterioration of the socio-economic situation of the region as a whole. There remains the question of formation of successful development strategies of Odessa regional banks in order to maintain and further improve their competitiveness. The choice of strategy is feasible according to the matrix of the competitive position of banking institutions in the sectors of baking markets (tabl. 6).

In all the studied segments for 2010 - 2014 there are no more than two leading banks and banks direct competitors. The vast number of banking institutions in its market share can be ranked to bank outsiders. There are some basic characteristics and strategies for each group of the banks. Banks, which operate in accordance with the marketing strategies of the Market leader and protect their competitive position, maintain the financial stability and increase the competitiveness of products and services (banks-leaders, for example, Privatbank).

Choosing of the Second market leader marketing strategy provides the orientation of banks to the improvement of competitiveness of all sectors of the bank market (direct competitors, for example, Ukreksimbank, Oshchadbank, Bank Pivdenny).

According to the marketing strategies of the Challenger, the priority for banks is the development of measures for improvement the results of performance: adjustment of the strategy development, improvement of the efficiency of financial management, the introduction of innovative bank products and technologies, increasing of the resource base, adjusting credit-deposit, pricing and marketing policies, etc. (potentional competitors, for example, Delta Bank, Prominvestbank, PUMB, VTB Bank).

Strategic objective of the bank, according to the Niche marketing strategies, is the development of new market segments, reorientation of the target markets of services, reduction of non-profit activities, the optimization of the level of risk for banking operations, the expansion of the customer base, offering the new high quality or modified services on the existing market segments, etc. (banks outsiders, for example, Investbank, Misto Bank, Platinum Bank, Kredobank, Ukrinbank, Ukrsybbank, OTP Bank, Union Standard Bank etc.).

The conclusions. One of the problems of the banking system in our country is the imbalance of its regional component. In particular, regional banks have to attract the maximum number of local resources, but the funds are used not for the development of the regions, but for the areas, which have the significantly higher demands for credit resources and high interest rates for their usage.

A possible way to deal with this situation is to organize and develop the regional systems of commercial banks. 
Table 6

Matrix of the competitive position of banking institutions among the sectors of the banking market in Odessa region during 2010 - 2014*)

\begin{tabular}{|c|c|c|c|c|c|c|c|c|c|c|}
\hline \multirow{2}{*}{. } & \multirow{2}{*}{ 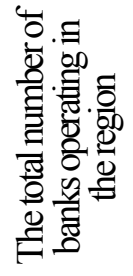 } & \multirow{2}{*}{ 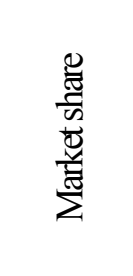 } & \multicolumn{2}{|c|}{$\begin{array}{l}\text { Banks market } \\
\text { leaders }\end{array}$} & \multicolumn{2}{|c|}{ Banks challengers } & \multicolumn{2}{|c|}{$\begin{array}{l}\text { Banks potential } \\
\text { competitors }\end{array}$} & \multicolumn{2}{|c|}{ Banks outsiders } \\
\hline & & & 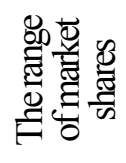 & 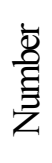 & 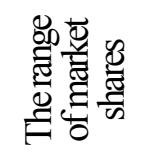 & 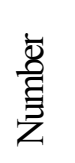 & 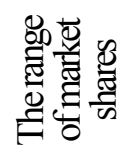 & $\begin{array}{l}\bar{\circlearrowright} \\
\bar{\Xi} \\
\bar{z}\end{array}$ & 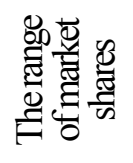 & $\begin{array}{l}\dot{\mathrm{\mho}} \\
\text { छ्ञ } \\
\text { Z }\end{array}$ \\
\hline \multirow{4}{*}{ 응 } & \multirow{4}{*}{90} & Assets & $\begin{array}{l}0,0843- \\
0,1122\end{array}$ & 2 & $\begin{array}{l}0,0562- \\
0,0842\end{array}$ & 1 & $\begin{array}{l}0,0281- \\
0,0561\end{array}$ & 6 & $0-0,0280$ & 81 \\
\hline & & Loans & $\begin{array}{c}0,0818- \\
0,1091\end{array}$ & 2 & $\begin{array}{c}0,0546- \\
0,0818\end{array}$ & 2 & $\begin{array}{c}0,0273- \\
0,0545\end{array}$ & 7 & $0-0,0273$ & 79 \\
\hline & & Deposits & $\begin{array}{l}0,1024 \\
0,1364\end{array}$ & 2 & $\begin{array}{l}0,0683- \\
0,1023\end{array}$ & 1 & $\begin{array}{c}0,0342- \\
0,0682\end{array}$ & 5 & $0-0,0341$ & 82 \\
\hline & & $\begin{array}{l}\text { Financial } \\
\text { result }\end{array}$ & $\begin{array}{c}0,2071- \\
0,2760\end{array}$ & 1 & $\begin{array}{l}0,1381- \\
0,2070\end{array}$ & 1 & $\begin{array}{c}0,0700- \\
0,1380\end{array}$ & 3 & $0-0,0699$ & 85 \\
\hline \multirow{4}{*}{ సี } & \multirow{4}{*}{83} & Assets & $\begin{array}{c}0,0968- \\
0,1290\end{array}$ & 2 & $\begin{array}{l}0,0645- \\
0,0967\end{array}$ & 1 & $\begin{array}{l}0,0323- \\
0,0644\end{array}$ & 5 & $0-0,0322$ & 75 \\
\hline & & Loans & $\begin{array}{c}0,1044 \\
0,1391\end{array}$ & 1 & $\begin{array}{l}0,0696- \\
0,1043\end{array}$ & 2 & $\begin{array}{l}0,0349- \\
0,0695\end{array}$ & 3 & $0-0,0348$ & 77 \\
\hline & & Deposits & $\begin{array}{c}0,1033- \\
0,1375\end{array}$ & 2 & $\begin{array}{l}0,0689- \\
0,1032\end{array}$ & 1 & $\begin{array}{c}0,0345- \\
0,0688\end{array}$ & 6 & $0-0,0344$ & 74 \\
\hline & & $\begin{array}{l}\text { Financial } \\
\text { result }\end{array}$ & $\begin{array}{c}0,2731- \\
0,3639\end{array}$ & 1 & $\begin{array}{l}0,1821- \\
0,2730\end{array}$ & 0 & $\begin{array}{c}0,0911- \\
0,1820\end{array}$ & 1 & $0-0,0910$ & 81 \\
\hline \multirow{4}{*}{$\stackrel{\nabla}{\stackrel{d}{\circ}}$} & \multirow{4}{*}{77} & Assets & $\begin{array}{c}0,1308- \\
0,1742\end{array}$ & 1 & $\begin{array}{l}0,0872- \\
0,1307\end{array}$ & 2 & $\begin{array}{l}0,0437- \\
0,0871\end{array}$ & 2 & $0-0,0436$ & 72 \\
\hline & & Loans & $\begin{array}{c}0,1139- \\
0,1517\end{array}$ & 1 & $\begin{array}{c}0,0787- \\
0,1138\end{array}$ & 1 & $\begin{array}{l}0,0380- \\
0,0786\end{array}$ & 3 & $0-0,0379$ & 72 \\
\hline & & Deposits & $\begin{array}{l}0,1219- \\
0,1624\end{array}$ & 1 & $\begin{array}{l}0,0813- \\
0,1218\end{array}$ & 1 & $\begin{array}{l}0,0407- \\
0,0812\end{array}$ & 3 & $0-0,0406$ & 72 \\
\hline & & $\begin{array}{l}\text { Financial } \\
\text { result }\end{array}$ & $\begin{array}{c}0,2041- \\
0,2720\end{array}$ & 1 & $\begin{array}{c}0,1361- \\
0,2040\end{array}$ & 0 & $\begin{array}{c}0,0681- \\
0,1360\end{array}$ & 5 & $0-0,0680$ & 71 \\
\hline
\end{tabular}

*) Source: constructed by the authors on [10] based on realistic data reporting banks

The development of this phenomenon requires a search for the adequate methods of assessment, that enough to determine the current state and prospects for growth in the banking sector and to develop the possible strategies for the development of regional banks, taking into account the factors, that influence the activity of the regional bank.

\section{Література}

1. Герасимчук, 3. В. Територіальна організація банківської системи регіонів України: оцінка та стратегії забезпечення іiі раціональності [Текст] : монографія / [3. В. Герасимчук, Н. І. Корецька]. - Луц. нац. техн. ун-т, 2010, $309 \mathrm{c}$.

2. Корецька, Н. І. Модель розвитку регіонального банку [Текст] / Н. І. Корецька // Актуальні проблеми розвитку економіки регіону : зб. наук. праць. - Івано-Франківськ, 2011. - Вип. 7. - Т.1 - С. 64-67.

3. Гуляєва, Л. Регіональні аспекти функціонування комерційних банків України [Текст]/ Л. Гуляєва // Вісник ТДЕУ. - Тернопіль : Економічна думка, 2006. - № 1. - С. 36-41.

4. Другов, О. О. Політика регіонального розвитку банківської системи України [Текст] / О.О.Другов // Вісник Української академії банківської справи. - 2006. - № 1. - С. 56-60.

5. Кремер, К. И. Система показателей для институционального анализа региональных банковских систем [Текст] / К. И. Кремер // Вестник ВГУ. - 2004. - №1. - С. 71-75.

6. Копилюк, О. Проблеми формування регіональної політики розвитку банківської системи України [Електронний pecypc]

О. Копилюк.

Режим доступу: 
http://sopus.at.ua/publ/2014_11_25_lviv/sekcja_3_2014_11_25/problemi_formuvannja_regionalnoi_politiki_bankivskoi_poli tiki_rozvitku_bankivskoji_sistemi_ukrajini/69-01-0-1118.

7. Копилюк, О. І. Вплив фінансово-економічної кризи на формування регіональної політики розвитку банківської системи України [Текст] / О. І. Копилюк // БІЗНЕС-ІНФОРМ. - 2014. - № 9. - С. 254-259.

8. Про банки і банківську діяльність [Електронний ресурс] : закон України, затверджений Верховною Радою України від 07.12.2000, № 2121-III. - Режим доступу: http://zakon4.rada.gov.ua/laws/show/2121-14. - Назва 3 домашньої сторінки Інтернету.

9. О банках и банковской деятельности [Электронный ресурс] : Федеральный Закон Российской Федерации от 02.12.1990, № 395-1. - Режим доступа: http:/www.consultant.ru. - Название с экрана.

10. Банківський нагляд. Основні показники діяльності банків України. Дані фінансової звітності банків України [Електронний ресурс]. - Режим доступу: http://www.bank.gov.ua. - Офіційний сайт Національного банку України.

11. Статистичні спостереження. Регіональна статистика [Електронний ресурс]. - Режим доступу: //http://www.ukrstat.gov.ua. - Офіційний сайт Державної служби статистики України.

12. Качан, Э. П. Регіональна економіка [Текст] : підручник / Є. П. Качан. - Тернопіль : ТНЕУ, 2008. $800 \mathrm{c}$.

13. Дробишевский, С. Региональные банковские системы и инвестиционные процессы [Текст] / [С. Дробишевский, П. Трунин, С. Четвериков, Л. Ледерман] : Консорциум по вопр. приклад. эконом. исслед. Канадск. агентство по междунар. развитию. - М. : ИЭПП, 2007. - 134 с.

14. Завадська, Д. В. Маркетинг у банку: теорія та методологія [Текст] : монографія / [Д. В. Завадська, Л. В. Жердецька, Л. В. Кузнєцова]. - Одеса : Видавництво «Атлант». - 2010. - 717 с.

15. Самойлов, Г. О. Банковская конкуренция [Текст] / Г. О. Самойлов, А. Г. Бачалов. - М. : Экзамен, 2002. $-256 \mathrm{c}$.

16. Дяченко, Т. О. Визначення конкурентоспроможності автотранспортних підприємств та стратегії іiі підвищення [Текст] : автореф. дис. ... канд. економ. наук. : 08.07.04 - Економіка та управління підприємством / Т. О. Дяченко. - Київ, 2002. - 12 с.

\section{References}

1. Herasymchuk, Z. V., \& Koretska, N. I. (2010). Terytorialna orhanizatsiia bankivskoi systemy rehioniv Ukrainy: otsinka ta stratehii zabezpechennia ii ratsionalnosti (The Bank System Territorial Organization of Regions in Ukraine: assessment and rationalization strategy). LNTU, Lutsk, Ukraine.

2. Koretska, N. I. (2011). The Model of Regional Bank Development. Aktualni problemy rozvytku ekonomiky rehionu, 7, 64-67.

3. Huliaieva, L. (2006). The Regional Aspects of Commercial Banks Performance in Ukraine. Visnyk TDEU, 1, $36-41$.

4. Druhov, O. O. (2006). The Policy of Regional Banking System Development in Ukraine. Visnyk Ukrainskoi akademii bankivskoi spravy, 1, 56-60.

5. Kremer, K. I. (2004). The system of indicators for institutional analysis of Regional Banking Systems. Vestnik VHU, 1, 71-75.

6. Kopyliuk, O. (2014). Problems of Regional Policy Development of Ukraine`s Banking System. Available at http://sopus.at.ua/publ/2014_11_25_lviv/sekcja_3_2014_11_25/problemi_formuvannja_regionalnoi_politiki_bankivskoi_poli tiki_rozvitku_bankivskoji_sistemi_ukrajini/69-01-0-1118

7. Kopyliuk, O. I. (2014). The Impact of Financial Crisis on Regional Policy Development of Ukraine's Banking System. BIZNESINFORM, 9, 254-259.

8. The Verhovna Rada of Ukraine. (2000). The Law of Ukraine. On the Banks and Bank Activity. Available at http://zakon4.rada.gov.ua/laws/show/2121-14

9. The Verkhovnyi Sovet of Russian Federation. (1990). On the Banks and Bank Activity. The Law of Russian Federation. Available at http://www.consultant.ru/

10. National Bank of Ukraine. (2015). Bank Supervision. Main Indicators of Ukraine`s Banks Activity. Available at http://www.bank.gov.ua/

11. State Statistics Service of Ukraine. (2015). Statistical Observation. Regional Statistics. Available at http://www.ukrstat.gov.ua

12. Kachan, Ye. P. (2008). Rehionalna ekonomika (Regional Economics). TNEU, Ternopil, Ukraine.

13. Drobyshevskiy, S., Trunin, P., Chetverikov, S., \& Lederman, L. (2007). Regionalnye bankovskie sistemy $i$ investitsyonnye protsessy (Regional Bank System and Investment Processes). Moscow.

14. Zavadska, D. V. (2010). Marketynh u banku: teoriia ta metodolohiia (Bank marketing: theory and methodology). Odessa: Atlant.

15. Samoylov, G. O. (2002). Bankovskaia konkurentsyia (The Bank concentration). Moscow: Ekzamen.

16. Diachenko, T. O. (2002). Definition of Competitiveness and Improvement Strategy of Automobile Transportation Companies. Kyiv. 